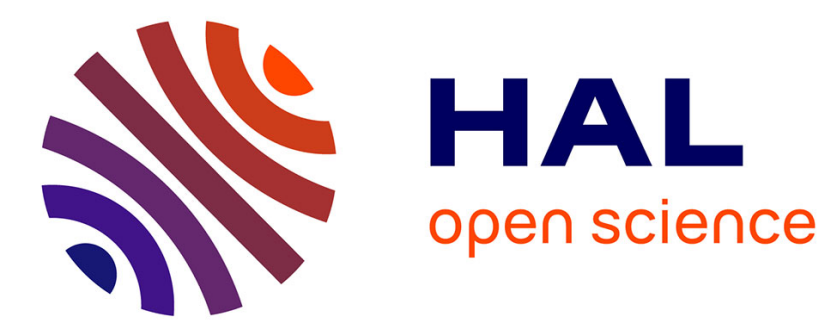

\title{
Peptidoglycan and Nod Receptor
}

Richard Wheeler, Frédéric Veyrier, Catherine Werts, Ivo Gomperts Boneca

\section{To cite this version:}

Richard Wheeler, Frédéric Veyrier, Catherine Werts, Ivo Gomperts Boneca. Peptidoglycan and Nod Receptor. Taniguchi N., Endo T., Hart G., Seeberger P., Wong CH. (eds). Glycoscience: Biology and Medicine, Springer Japan, pp.737-747, 2015, 978-4-431-54841-6.10.1007/978-4-431-54841-6_147 . pasteur-02337884

\section{HAL Id: pasteur-02337884 \\ https://hal-pasteur.archives-ouvertes.fr/pasteur-02337884}

Submitted on 29 Oct 2019

HAL is a multi-disciplinary open access archive for the deposit and dissemination of scientific research documents, whether they are published or not. The documents may come from teaching and research institutions in France or abroad, or from public or private research centers.
L'archive ouverte pluridisciplinaire $\mathbf{H A L}$, est destinée au dépôt et à la diffusion de documents scientifiques de niveau recherche, publiés ou non, émanant des établissements d'enseignement et de recherche français ou étrangers, des laboratoires publics ou privés.

\section{(ㅇ)(1) 80}

Distributed under a Creative Commons Attribution - NonCommercial - ShareAlikel 4.0 


\title{
Peptidoglycan and Nod Receptor
}

\section{Richard Wheeler, Frédéric Veyrier, Catherine Werts, and Ivo Gomperts Boneca}

\author{
R. Wheeler • C. Werts $\bullet$ I.G. Boneca $(*)$
}

Biology and Genetics of the Bacterial Cell Wall Unit, Institut Pasteur, Paris cedex 75, France

Inserm, Group Avenir, Paris, France

e-mail: rwheeler@pasteur.fr; cwerts@pasteur.fr; bonecai@pasteur.fr

F. Veyrier

Biology and Genetics of the Bacterial Cell Wall Unit, Institut Pasteur, Paris cedex 75, France

Inserm, Group Avenir, Paris, France

Invasive Bacterial Infections Unit, Institut Pasteur, Paris cedex 75, France

Microbiology, Molecular Biology and Evolutionary Biology, Institut Pasteur in Paris, Paris, France

e-mail: frederic.veyrier@iaf.inrs.ca

\begin{abstract}
Bacterial cells are encompassed by a macromolecular network of peptidoglycan, the major component of bacterial cell walls that provides the cell wall strength and determines bacterial morphology. Eukaryotic organisms sense the presence of bacteria by detecting peptidoglycan fragments shed by the bacterium or released through hydrolytic attack by host enzymes. As such, peptidoglycan plays a major role in regulation of host inflammatory homeostasis and has a remarkable variety of influences on the physiological development of the host.

This chapter describes the tools necessary to characterize both the biochemistry and biological activity of peptidoglycans purified from a broad range of bacteria. These protocols detail the procedures for purification of peptidoglycan and analysis of its composition by reversed-phase high-performance liquid chromatography (HPLC), taking into account the specific requirements for different types of bacteria, and describe a NF- $x$ Bluciferase reporter assay performed using the HEK293T human epithelial cell line, to assess the biological activity of purified peptidoglycans through recognition by mammalian Nod-like receptors Nod1 and Nod2.
\end{abstract}

\section{Keywords}

Peptidoglycan, Gram-negative, Gram-positive, Mycobacterium, Nod1, Nod2, NF- $\varkappa$ B, Cell wall

\section{Introduction}

Peptidoglycan is a unique heteropolymer composed of glycans cross-linked by short stem peptides and is the major component of the bacterial cell wall. The glycans are built from repeating units of the disaccharide $N$ acetylglucosamine- $\beta(1,4)-N$-acetylmuramic acid. The stem peptides are attached to the lactyl moiety of the $N$ acetylmuramic acids and are composed of alternating 1- and d-amino acids with the following general sequence: 1-Ala, d-Glx, diamino acid (most frequently meso-diaminopimelic acid or l-lysine), d-Ala, d-Ala. The unique nature of the peptidoglycan has been co-opted during evolution by eukaryotes as a signal for the presence of bacteria in their environment. For example, invertebrates use a variety of peptidoglycan recognition proteins (PGRPs; Gottar et al. 2002; Michel et al. 2001) to sense peptidoglycan, while mammals use the Nod-like receptors (NLRs) Nod1 and Nod2 (Girardin et al. 2003a, b). The last decade has generated much work on the structure, recognition, and specificity of these receptors (Girardin et al. 2003c). However, despite a common building block, the mature peptidoglycan is highly heterogeneous and species specific. Thus, to ascertain the biological activity of the peptidoglycan of a given species, the preparation of a highly purified peptidoglycan is required, free of other cell wall components such as lipoproteins, secondary polysaccharides, lipopolysaccharides, lipoteichoic acids, and many other components that are often species or genus specific (Travassos et al. 2004). Once purified, the peptidoglycan biological activity towards the peptidoglycan receptors 
Nod1 and Nod2 can be tested in cellular assays using luciferase reporter systems (Travassos et al. 2004) (Figs. 1 and 2).

\section{Protocol I: Peptidoglycan Purification}

Peptidoglycan purification methods vary for different types of bacteria. As far as possible, the following is a single protocol that can be applied to all bacteria. Please read through the protocol carefully, noting additional steps that may be required for your specific application. Additionally, toxic substances are used throughout these protocols. Read MSDS and use appropriate safety precautions (e.g., hydrofluoric acid (HF) is extremely hazardous and has a high reactivity towards glass and many metals; it is stored in compatible plastic containers).

\section{Stock buffers solutions and enzymes:}

1.

$8 \%$ SDS; SDS is purchased typically as a $20 \%$ solution. Dilute $200 \mathrm{ml}$ of $20 \%$ SDS in milli-Q (MQ) water to a final volume of $500 \mathrm{ml}$.

2 .

$0.5 \% \mathrm{KOH}$ in methanol-diethyl ether $(1: 1)$. Combine $100 \mathrm{ml}$ methanol with $100 \mathrm{ml}$ diethyl ether to produce a 1:1 methanol-diethyl ether solution. Dissolve $1 \mathrm{~g}$ of $\mathrm{KOH}$ in methanol-diethyl ether solution to a final volume of $200 \mathrm{ml}$.

3. $8 \mathrm{M} \mathrm{LiCl}$; dissolve $\mathrm{LiCl}$ (169.56 $\mathrm{g}$ ) in MQ water to a final volume of $500 \mathrm{ml}$.

4. 100 mM EDTA pH 8; dissolve EDTA (14.61 g) in $400 \mathrm{ml}$ MQ water. EDTA dissolves at basic pH. With continual mixing, gradually add $\mathrm{NaOH}$ pellets until the EDTA fully dissolves. Adjust the $\mathrm{pH}$ to 8.0, and then add MQ water to a final volume of $500 \mathrm{ml}$.

5. $1 \mathrm{M} \mathrm{MgSO}_{4}$; dissolve $\mathrm{MgSO}_{4}(60.16 \mathrm{~g})$ in MQ water to a final volume of $500 \mathrm{ml}$.

6. $1 \mathrm{M} \mathrm{CaCl}_{2}$; dissolve $\mathrm{CaCl}_{2}(55.49 \mathrm{~g})$ in MQ water to a final volume of $500 \mathrm{ml}$.

7. $\alpha$-amylase (Sigma; $10 \mathrm{mg} / \mathrm{ml}$ ); add $50 \mathrm{mg} \alpha$-amylase to $5 \mathrm{ml} \mathrm{MQ}$ water. Mix thoroughly, aliquot, and store at $-20{ }^{\circ} \mathrm{C}$.

8 . DNase (Sigma; $2 \mathrm{mg} / \mathrm{ml}$ ); add $10 \mathrm{mg}$ DNase to $5 \mathrm{ml} \mathrm{MQ}$ water. Mix thoroughly, aliquot, and store at $-20^{\circ} \mathrm{C}$.

9. RNase (Sigma; $10 \mathrm{mg} / \mathrm{ml}$ ); add $50 \mathrm{mg}$ RNase to $5 \mathrm{ml} \mathrm{MQ}$ water. Mix thoroughly, aliquot, and store at $-20^{\circ} \mathrm{C}$.

10.

Trypsin ( $3 \mathrm{X}$ crystallized from Worthington; $10 \mathrm{mg} / \mathrm{ml}$ ); add $50 \mathrm{mg}$ trypsin to $5 \mathrm{ml} \mathrm{MQ}$ water. Mix thoroughly, aliquot, and store at $-20^{\circ} \mathrm{C}$.

\section{Protocol:}

\section{Steps 1-9 for All Bacteria}

- 1.

Grow $500 \mathrm{ml}$ liquid culture until required growth phase. Alternatively collect cells from agar plates if unable to grow in liquid media. 
- 2 .

Chill cells rapidly in an ice-ethanol bath for $10 \mathrm{~min}$.

- 3 .

Centrifuge cells at an appropriate speed for $30 \mathrm{~min}$ at $4{ }^{\circ} \mathrm{C}$.

- 4.

Resuspend the pellet in $10 \mathrm{ml}$ of ice-cold MQ water. It is recommended to use ultrapure endotoxin-free water when PG is intended for immunomodulatory assays (see protocol V).

- 5 .

Add the suspension dropwise to $10 \mathrm{ml}$ of $8 \%$ SDS preheated to $95^{\circ} \mathrm{C}$ (final SDS concentration is $4 \%$ ) in a 50 ml Erlenmeyer flask.

- 6.

Incubate at $95^{\circ} \mathrm{C}$ (to avoid bubbling) with constant agitation, for $4 \mathrm{~h}$.

- 7 .

Ultracentrifuge for $30 \mathrm{~min}$ and discard supernatant. All ultracentrifugations are performed at $150,000 \times g$ at room temperature (RT), unless otherwise specified, as SDS precipitates at low temperature.

- 8.

Wash by resuspension in MQ water at RT and ultracentrifugation as in step 7 or in $1.5 \mathrm{ml}$ microfuge tubes in a micro-ultracentrifuge.

- 9.

Repeat step 8 until the supernatant is free of SDS (at least seven washes). Check for the presence of SDS as described in Protocol IV.

Protocol complete for Gram-negative bacteria with PG lacking covalently attached lipoproteins, for applications that do not require ultrapure PG. Lyophilize and weigh the pellet. Store at $-20{ }^{\circ} \mathrm{C}$.

\section{Steps 10-12 for Mycobacteria and Other Actinobacteria Only. Otherwise Go to Step 13}

- 10

To hydrolyze mycolic acids by saponification, resuspend the pellet in $1 \mathrm{ml} 0.5 \% \mathrm{KOH}$ in methanol-diethyl ether $(1: 1)$.

- 11 .

Incubate at RT for $96 \mathrm{~h}$ with agitation.

- 12 .

Wash twice by resuspension with $1 \mathrm{ml} 100 \%$ methanol and ultracentrifugation.

\section{Steps 13-16 for Gram-Positive Bacteria Only. Otherwise Go to Step 17}

- 13.

Resuspend the pellet in $0.5 \mathrm{ml} \mathrm{MQ}$ water and transfer to $2 \mathrm{ml}$ screw cap tubes with an equal volume of $\leq 106 \mu \mathrm{m}$ acid-washed glass beads. For large pellets, aliquot into several tubes. 
- 14 .

Break the cells using a cell homogenizer (e.g., FastPrep-24, MP Biomedicals) according to manufacturer protocols. Confirm cell breakage by microscopy.

- 15 .

Separate the broken cells from glass beads by vacuum filtration through sintered glass (ASTM 40-60 C). Apply $15 \mathrm{ml}$ of MQ water to the glass beads and filter again. Transfer cell suspension to ultracentrifuge tubes.

- 16 .

Ultracentrifuge for $30 \mathrm{~min}$ at RT and discard the supernatant.

\section{Steps 17-22 for All Bacteria}

- 17 .

Resuspend the pellet in $50 \mathrm{mM}$ Tris $\mathrm{pH} 7.0$ pre-warmed to $37^{\circ} \mathrm{C}$.

- 18 .

Add $\alpha$-amylase $\left(100 \mu \mathrm{g} / \mathrm{ml}\right.$ final) and incubate overnight at $37^{\circ} \mathrm{C}$.

- 19.

Add $\mathrm{MgSO}_{4}\left(20 \mathrm{mM}\right.$ final), DNase $(10 \mu \mathrm{g} / \mathrm{ml})$ and RNase $(50 \mu \mathrm{g} / \mathrm{ml})$ and incubate at $37^{\circ} \mathrm{C}$ for $2 \mathrm{~h}$.

- 20.

Add $\mathrm{CaCl}_{2}(10 \mathrm{mM}$ final $)$ with trypsin $(100 \mu \mathrm{g} / \mathrm{ml}$ final $)$ and incubate overnight at $37^{\circ} \mathrm{C}$.

- 21 .

Add SDS to a final concentration of $1 \%$. Incubate the suspension at $95{ }^{\circ} \mathrm{C}$ for $15 \mathrm{~min}$ with constant agitation.

- 22 .

Ultracentrifuge for $30 \mathrm{~min}$ at RT and discard the supernatant.

\section{Steps 23-24 for Gram-Negative Bacteria Only. Otherwise Go to Step 25}

- 23 .

Wash by resuspension in MQ water and ultracentrifugation.

- 24.

Repeat step 23 until the supernatant is free of SDS (at least seven washes). Check for the presence of SDS as described in Protocol IV.

Protocol complete for Gram-negative bacteria. Lyophilize and weigh the pellet. Store at $-20{ }^{\circ} \mathrm{C}$.

\section{Steps 25-41 for All Bacteria Excluding Gram-Negative Bacteria}

- 25 .

Wash once by resuspension in MQ water and ultracentrifugation. Discard the supernatant.

- 26 .

Resuspend the pellet in $10 \mathrm{ml}$ of $\mathrm{LiCl}(8 \mathrm{M})$, pre-warmed to $37^{\circ} \mathrm{C}$. Incubate for $15 \mathrm{~min}$ at $37^{\circ} \mathrm{C}$ with constant agitation. 
- 27.

Ultracentrifuge the suspension for $30 \mathrm{~min}$. Discard the supernatant.

- 28 .

Resuspend the pellet in $10 \mathrm{ml}$ of EDTA pH $8(100 \mathrm{mM})$, pre-warmed to $37^{\circ} \mathrm{C}$. Incubate for 15 min at $37^{\circ} \mathrm{C}$ with constant agitation.

- 29 .

Ultracentrifuge the suspension for $30 \mathrm{~min}$. Discard the supernatant.

- 30 .

Wash twice by resuspension in MQ water and ultracentrifugation. Discard the supernatant.

- 31 .

In an acetone-resistant tube (e.g., polyallomer), add $10 \mathrm{ml}$ of acetone to the pellet and sonicate for $15 \mathrm{~min}$ in an ultrasonic bath. The pellet should resuspend during sonication.

- 32 .

Ultracentrifuge the suspension for $30 \mathrm{~min}$. Discard the supernatant.

- 33 .

Wash twice by resuspension in MQ water and ultracentrifugation. Discard the supernatant.

- 34 .

Lyophilize and weigh the pellet.

NB: At this stage of the purification, the PG retains labile covalent modifications such as $O$-acetylated groups which may be desired for analysis.

- 35 .

Add $1 \mathrm{ml}$ of HF per $2.5 \mathrm{mg}$ of pellet in polypropylene/polyallomer tubes.

NB: HF is extremely hazardous. Do not attempt to use without receiving specific training on handling, disposal, and decontamination. All solutions should be maintained at $4{ }^{\circ} \mathrm{C}$ to reduce vapor.

- 36 .

Incubate at $4{ }^{\circ} \mathrm{C}$ for $96 \mathrm{~h}$ with constant stirring.

- 37.

Ultracentrifuge for $30 \mathrm{~min}$ in a micro-ultracentrifuge at $4{ }^{\circ} \mathrm{C}$. Discard supernatant.

- 38 .

Wash twice by resuspension in MQ water and ultracentrifugation. Discard the supernatant.

- 39 .

Wash twice by resuspension in $50 \mathrm{mM}$ Tris $\mathrm{pH} 7.0$ and ultracentrifugation. Discard the supernatant.

- 40 .

Wash once by resuspension in MQ water and ultracentrifugation. Discard the supernatant.

- 41.

Lyophilize and weigh the pellet. 


\section{Protocol Complete for Gram-Positive Bacteria, Mycobacteria and Other Actinobacteria. Store at $-20{ }^{\circ} \mathrm{C}$}

\section{Protocol II: Peptidoglycan Digestion by Mutanolysin}

Stock buffers, solutions, and enzymes:

- 1 .

Mutanolysin from Streptomyces globisporus ATCC 21553 (Sigma; $10 \mathrm{mg} / \mathrm{ml}$ ); the precise quantity of mutanolysin purchased varies between batches and is indicated on the vial. Resuspend to a final concentration of $10 \mathrm{mg} / \mathrm{ml}$ in MQ water. Mix thoroughly, then aliquot into $50 \mu \mathrm{l}$ volumes, and store at $-20^{\circ} \mathrm{C}$.

- 2 .

$100 \mathrm{mM}$ sodium phosphate buffer pH 5.6 stock; combine $7.9 \mathrm{ml} 1 \mathrm{M} \mathrm{Na}_{2} \mathrm{HPO}_{4}$ with $92.1 \mathrm{ml} 1 \mathrm{M} \mathrm{NaH}_{2} \mathrm{PO}_{4}$ and add MQ water to a total volume of $950 \mathrm{ml}$. Adjust the $\mathrm{pH}$ to 5.6 with orthophosphoric acid and bring the final volume to $1 \mathrm{~L}$. Autoclave or filter sterilize.

- 3 .

$0.5 \mathrm{M}$ sodium borate buffer $\mathrm{pH}$ 9; dissolve boric acid powder (15.46 g) in $400 \mathrm{ml} \mathrm{MQ}$ water. Adjust the $\mathrm{pH}$ to 9 with $\mathrm{NaOH}$. Adjust the final volume to $500 \mathrm{ml}$ with MQ water. In the case of PGs with $O$-acetyl groups, adjust it to $\mathrm{pH} 8$.

\section{Protocol:}

- 1 .

Resuspend PG to the desired concentration in MQ water.

- 2 .

Resuspend 200-750 $\mu \mathrm{g}$ of PG in $190 \mu 12.5$ mM sodium phosphate buffer (pH 5.6) and $100 \mu \mathrm{g}$ of mutanolysin.

- 3 .

Incubate at $37^{\circ} \mathrm{C}$ for $16 \mathrm{~h}$ with agitation.

- 4 .

Boil the samples for 10 min to stop the reaction.

- 5

Centrifuge in a microfuge for $5 \mathrm{~min}$ at maximum speed and transfer the supernatant to a $2 \mathrm{ml}$ tube.

- 6 .

To reduce sugar moieties, add an equal volume of $0.5 \mathrm{M}$ sodium borate buffer ( $\mathrm{pH} 9.0$; in the case of PGs with $O$-acetyl groups, use a pH 8 instead). Add sodium borohydride $(10 \mathrm{mg} / \mathrm{ml}$ final) and mix thoroughly. Be careful as the reaction is effervescent.

- 7 .

Incubate for $15 \mathrm{~min}$ at $\mathrm{RT}$.

- 8 .

Stop the reaction by slowly adding orthophosphoric acid until the solution reaches $\mathrm{pH} 2$ (check by spotting 0.5 $\mu l$ of the reaction onto $\mathrm{pH}$ paper). Be careful as the reaction is effervescent.

- 9.

Centrifuge with a microfuge for $5 \mathrm{~min}$ at maximum speed. Supernatants may be filtered using 4 mm Acrodisc syringe filters. 
- 10 .

Transfer the supernatant to a conical bottom glass vial suitable for HPLC.

\section{Protocol III: Muropeptide Analysis by Reversed-Phase HPLC}

\section{Stock Buffers, Solutions, and Enzymes}

All buffers for HPLC must be degassed before use. Modern HPLC systems typically include an online degassing module. Check before use.

\section{- 1 .}

Buffer A(G-) 50 mM NaH $\mathrm{PO}_{4} \mathrm{pH} 4.3$; dissolve $\mathrm{NaH}_{2} \mathrm{PO}_{4}$ monohydrate (13.8 g) in $1.8 \mathrm{~L}$ of HPLC super gradient grade water. Adjust $\mathrm{pH}$ to 4.3 , and then add water to a final volume of $2 \mathrm{~L}$. Filter using mixed cellulose ester filters and autoclave the solution.

\section{- 2 .}

Buffer $\mathrm{B}(\mathrm{G}-) 75 \mathrm{mM} \mathrm{NaH}_{2} \mathrm{PO}_{4} \mathrm{pH} 4.9$ with $15 \%$ methanol; dissolve $\mathrm{NaH}_{2} \mathrm{PO}_{4}$ monohydrate $(20.7 \mathrm{~g})$ in $1.5 \mathrm{~L}$ of HPLC super gradient grade water. Adjust $\mathrm{pH}$ to 4.9, and then add water to a final volume of $1.7 \mathrm{~L}$. Add $300 \mathrm{ml}$ of HPLC grade methanol and mix thoroughly. Filter using $0.2 \mu \mathrm{m}$ PVDF filters.

- 3 .

Buffer $\mathrm{A}(\mathrm{G}+) 10 \mathrm{mM} \mathrm{NH}_{4} \mathrm{H}_{2} \mathrm{PO}_{4} \mathrm{pH}$ 5.6; dissolve $\mathrm{NH}_{4} \mathrm{H}_{2} \mathrm{PO}_{4}(2.3 \mathrm{~g})$ in $1.8 \mathrm{~L}$ of HPLC super gradient grade water. Adjust $\mathrm{pH}$ to 5.6, and then add water to a final volume of $2 \mathrm{~L}$. Filter and autoclave the solution.

- 4.

Buffer $\mathrm{B}(\mathrm{G}+) 10 \mathrm{mM} \mathrm{NH}_{4} \mathrm{PO}_{4} \mathrm{pH} 5.6$ with $30 \%$ methanol; dissolve $\mathrm{NH}_{4} \mathrm{H}_{2} \mathrm{PO}_{4}(2.3 \mathrm{~g})$ in $1.2 \mathrm{~L}$ of HPLC super gradient grade water. Adjust $\mathrm{pH}$ to 5.6, and then add water to a final volume of 1.4 L. Add $600 \mathrm{ml}$ of HPLC grade methanol and mix thoroughly. Filter using 0.2 $\mu \mathrm{m}$ PVDF filters.

- 5 .

Buffer A(Ds) $0.05 \%$ Trifluoroacetic acid (TFA); add $1 \mathrm{ml}$ of TFA to $2 \mathrm{~L}$ of HPLC super gradient grade water.

- 6 .

Buffer B(Ds) $0.05 \%$ TFA with $50 \%$ acetonitrile; add $1 \mathrm{ml}$ of TFA to 11 of HPLC super gradient grade water, and then mix with $1 \mathrm{~L}$ of HPLC grade acetonitrile.

\section{Protocol:}

- 1 .

Set up an HPLC system such as the LC20 Shimadzu system, equipped with a Hypersil octyldecyl silane (C18) column $(4.6 \times 250 \mathrm{~mm})$ at $52{ }^{\circ} \mathrm{C}$, with a flow rate of $0.5 \mathrm{ml} / \mathrm{min}$. Muropeptides are detected at a $206 \mathrm{~nm}$ wavelength using, for example, a Shimadzu SPD-20A-UV-Vis detector.

- 2 .

Wash the storage solution (typically $80 \%$ methanol) from the column, and then equilibrate with at least five column volumes of the appropriate buffer B then buffer A.

- 3 .

The gradient conditions are as follows depending on the analysis: 
(a) Gram-negative-type PG and Gram-positive meso-DAPNH${ }_{2}$-type PG:

Use a 0-100\% buffer B linear gradient over $160 \mathrm{~min}$.

Buffer A(G-): $50 \mathrm{mM} \mathrm{NaH} \mathrm{PO}_{4} \mathrm{pH} 4.3$.

Buffer B(G-): 75 mM NaH${ }_{2} \mathrm{PO}_{4}$ pH 4.9 with $15 \%$ methanol.

(b) Other Gram-positive-type PG:

Use a 0-100 \% buffer B linear gradient over $280 \mathrm{~min}$.

Buffer $\mathrm{A}(\mathrm{G}+)$ : $10 \mathrm{mM} \mathrm{NH}_{4} \mathrm{PO}_{4} \mathrm{pH}$ 5.6.

Buffer $\mathrm{B}(\mathrm{G}+): 10 \mathrm{mM} \mathrm{NH}_{4} \mathrm{PO}_{4} \mathrm{pH} 5.6$ with $30 \%$. methanol

(c) For desalting muropeptides (prior to mass spectrometry analysis):

Use a $0-50 \%$ buffer B linear gradient over $30 \mathrm{~min}$.

Buffer A(Ds): $0.05 \%$ TFA.

Buffer B(Ds): $0.05 \%$ TFA with $50 \%$ acetonitrile.

\section{Protocol IV: Verification of the Absence of SDS in PG Sample}

According to Hayashi et al. (1975)

\section{Stock buffers, solutions, and enzymes:}

- 1 .

$0.7 \mathrm{mM}$ phosphate buffer $\mathrm{pH} 7.2$; combine $19.6 \mathrm{ml}$ of $10 \mathrm{mM} \mathrm{NaH} \mathrm{PO}_{4}$ with $50.4 \mathrm{ml} 10 \mathrm{mM} \mathrm{Na}_{2} \mathrm{HPO}_{4}$. Adjust to $1 \mathrm{~L}$ with MQ water and autoclave.

- 2 .

$100 \times$ Methylene blue stock; dissolve methylene blue in MQ water to $0.5 \%(w / v)$. Combine 1 volume of chloroform with 20 volumes of $0.5 \%$ methylene blue. Store in the dark.

\section{Protocol:}

- 1

Dilute $100 \times$ methylene blue stock 1:100 $(v / v)$ in $0.7 \mathrm{mM}$ phosphate buffer $\mathrm{pH}$ 7.2. 
- 2 .

Take $500 \mu \mathrm{l}$ of supernatant from PG washes and mix with $250 \mu \mathrm{l}$ of the dilute methylene blue solution. Use MQ water instead of supernatant as a negative control.

- 3 .

Add $1.5 \mathrm{ml}$ chloroform.

- 4.

Vortex for $1 \mathrm{~min}$ and then allow to settle for $1 \mathrm{~min}$.

- 5 .

The unwanted presence of SDS will be indicated by a blue lower phase. SDS-free supernatant should be pink/clear.

\section{Protocol V: NF- $\nsim$ B Luciferase Assay of Muropeptide Recognition by Nod Proteins}

In this assay, the human epithelial cell line HEK293T, which does not express Nod2 and only minimal amounts of human Nod1, is transfected with a NF- $x$ B-luciferase reporter construct together with Nod1 or Nod 2 and $\beta$ galactosidase-expressing vectors. Muropeptides that cannot enter the cells must be co-transfected in order to stimulate the cytosolic Nod proteins, which will activate the NF- $x \mathrm{~B}$ promotor, resulting in luciferase expression. The activities of luciferase and $\beta$-galactosidase are measured from cellular lysates in the presence of their substrates, using a luminometer and ELISA reader, respectively. Results are expressed as relative light units, normalized to the $\beta$-galactosidase activity. Control muropeptides (MurTriDap as Nod1 agonist or MDP as Nod2 agonist) and digestion buffer should be added as positive and negative controls in each assay. Each sample should be tested in triplicate, and several concentrations should be tested. In each assay, a NF- $x \mathrm{~B}-$ luciferase control should be conducted without co-transfection of a Nod vector. As a first control of proper purification, non-digested PG should be tested for lack of TLR2 recognition (Travassos et al. 2004).

\section{Stock buffers, solutions, and enzymes:}

- 1 .

Complete DMEM medium low glucose with $5 \%$ fetal bovine serum.

- 2 .

Lysis buffer; $25 \mathrm{mM}$ Tris- $\mathrm{HCl} \mathrm{pH} 8,8 \mathrm{mM} \mathrm{MgCl}_{2}, 1 \%$ Triton X-100, $15 \%$ glycerol, and $1 \mathrm{mM}$ DTT added extemporaneously. Keep at $4{ }^{\circ} \mathrm{C}$.

- 3 .

Luciferin stock $1 \mathrm{mM}$; dissolve $10 \mathrm{mg}$ of Luciferin potassium salt in $36 \mathrm{ml}$ of potassium phosphate buffer ( $85 \mathrm{ml}$ $\mathrm{KH}_{2} \mathrm{PO}_{4} 1 \mathrm{M}+95 \mathrm{ml} \mathrm{K}_{2} \mathrm{HPO}_{4} 1 \mathrm{M}$ ) pH 7.8 (keep frozen aliquots).

- 4

Luciferin buffer; lysis buffer with 1 mM DTT, 1 mM ATP, $2 \mu$ Luciferin.

- 5 .

Z buffer; 0,06 $\mathrm{M} \mathrm{Na}_{2} \mathrm{HPO} 4,0.04 \mathrm{M} \mathrm{NaH}_{2} \mathrm{PO} 4,10 \mathrm{mM} \mathrm{KCL}, 1 \mathrm{mM} \mathrm{MgSO}$, adjusted to pH 7.

- 6 .

ONPG buffer; ONPG $4 \mathrm{mg} / \mathrm{ml}$ in $\mathrm{Z}$ buffer (keep in the dark at $4{ }^{\circ} \mathrm{C}$ ). 


\section{Protocol:}

- 1 .

HEK293T cells are seeded the day before the transfection in 24-well plates at a density of around $10^{5}$ cells in 1 $\mathrm{ml}$ of complete DMEM medium.

- 2 .

Thirty minutes before transfection, add per well the equivalent of $0.1-10 \mu$ of the non-digested or digested PG of interest at $5 \mathrm{mg} / \mathrm{ml}$ (nonreduced and reduced as a control since the activity towards Nod2 will be lost upon reduction) as well as control muropeptides at $100 \mathrm{nM}$.

- 3 .

Transfect cells when they are 30-50\% confluent. Fugene or Jet PEI transfecting reagents are commonly used. All media should be warmed to RT before use. Allow DNA/transfecting reagent complexes to form at RT for 30 min. Add carefully to the cells, since the HEK293T cells are loosely adherent.

DNA mix: Prepare a mixture of DNA corresponding, per well, to $50 \mathrm{ng}$ of $5 \mathrm{X}$ NF- $\varkappa \mathrm{B}$ luciferase reporter vector (Stratagene), $25 \mathrm{ng}$ of pCMV- $\beta$ Gal plasmid (Invitrogen), $1 \mathrm{ng}$ of pcDNA3-Nod1 or pcDNA3-Nod2 expression vectors, and $225 \mathrm{ng}$ of pCDNA3 plasmid in $20 \mu \mathrm{l}$ of endotoxin-free water.

For TLR2 test, instead of Nod1 or Nod2 expressing vector, add in the DNA mixture, a TLR2 expressing vector, and complete up to $300 \mathrm{ng}$ of total DNA with pCDNA3. Use Pam3cysSK4 as a positive control of TLR2 activation. TLR and Nod vectors and ligands can be purchased from InvivoGen. Several trials may be required to adjust the quantities of TLR2 or NOD expressing vectors to get proper activation upon positive control stimulation.

- 4.

Transfecting solution: Prepare a mixture of 1:100 (v/v) transfection reagent in DMEM without serum, corresponding to $100 \mu \mathrm{l}$ per well.

- 5 .

Formation of DNA complexes with transfecting reagent: Add the transfecting solution to the DNA mix. Do not vortex. Mix by inverting the tubes. Incubate at RT for $30 \mathrm{~min}$.

- 6.

Carefully add $120 \mu \mathrm{l}$ of DNA complexes onto the cells. Incubate $24 \mathrm{~h}$.

- 7 .

Lyse the cells by adding $100 \mu \mathrm{l}$ of lysis buffer in each well. Incubate $5 \mathrm{~min}$ at RT.

- 8 .

Prepare two 96-well plates, one for the measure of luciferase activity with a luminometer and a second for ELISA plate reader. For each well, transfer $10 \mu \mathrm{l}$ of the cell lysate to both plates.

- 9.

For luminometer measurements: Inject $50 \mu \mathrm{l}$ of luciferase buffer $2 \mathrm{~s}$ before reading.

- 10 .

For $\beta$-galactosidase assay: Add one volume of ONPG buffer to four volume of $\mathrm{Z}$ buffer. Add $100 \mu \mathrm{l}$ to each well. Use $10 \mu \mathrm{l}$ of lysis buffer as a negative control. Incubate at $37^{\circ} \mathrm{C}$ for $30 \mathrm{~min}$. Measure at a wavelength of 420 or $450 \mathrm{nM}$. 


\section{References}

1. Girardin SE, Boneca IG, Carneiro LA et al (2003a) Nod1 detects a unique muropeptide from Gramnegative bacterial peptidoglycan. Science 300:1584-1587

2. Girardin SE, Boneca IG, Viala J et al (2003b) Nod2 is a general sensor of peptidoglycan through muramyl dipeptide (MDP) detection. J Biol Chem 278:8869-8872

3. - Girardin SE, Travassos LH, Herve M et al (2003c) Peptidoglycan molecular requirements allowing detection by Nod1 and Nod2. J Biol Chem 278:41702-41708

4. - Gottar M, Gobert V, Michel T et al (2002) The Drosophila immune response against Gram-negative bacteria is mediated by a peptidoglycan recognition protein. Nature 416:640-644

5. · Hayashi K (1975) A rapid determination of sodium dodecyl sulfate with methylene blue. Anal Biochem 67:503-506

6. - Michel T, Reichhart JM, Hoffmann JA, Royet J (2001) Drosophila Toll is activated by Gram-positive bacteria through a circulating peptidoglycan recognition protein. Nature 414:756-759

7. - Travassos LH, Girardin SE, Philpott DJ et al (2004) Toll-like receptor 2-dependent bacterial sensing does not occur via peptidoglycan recognition. EMBO Rep 5:1000-1006

8. - Viala J, Chaput C, Boneca IG et al (2004) Nod1 responds to peptidoglycan delivered by the Helicobacter pylori cag pathogenicity island. Nat Immunol 5:1166-1174 


\section{Figures}

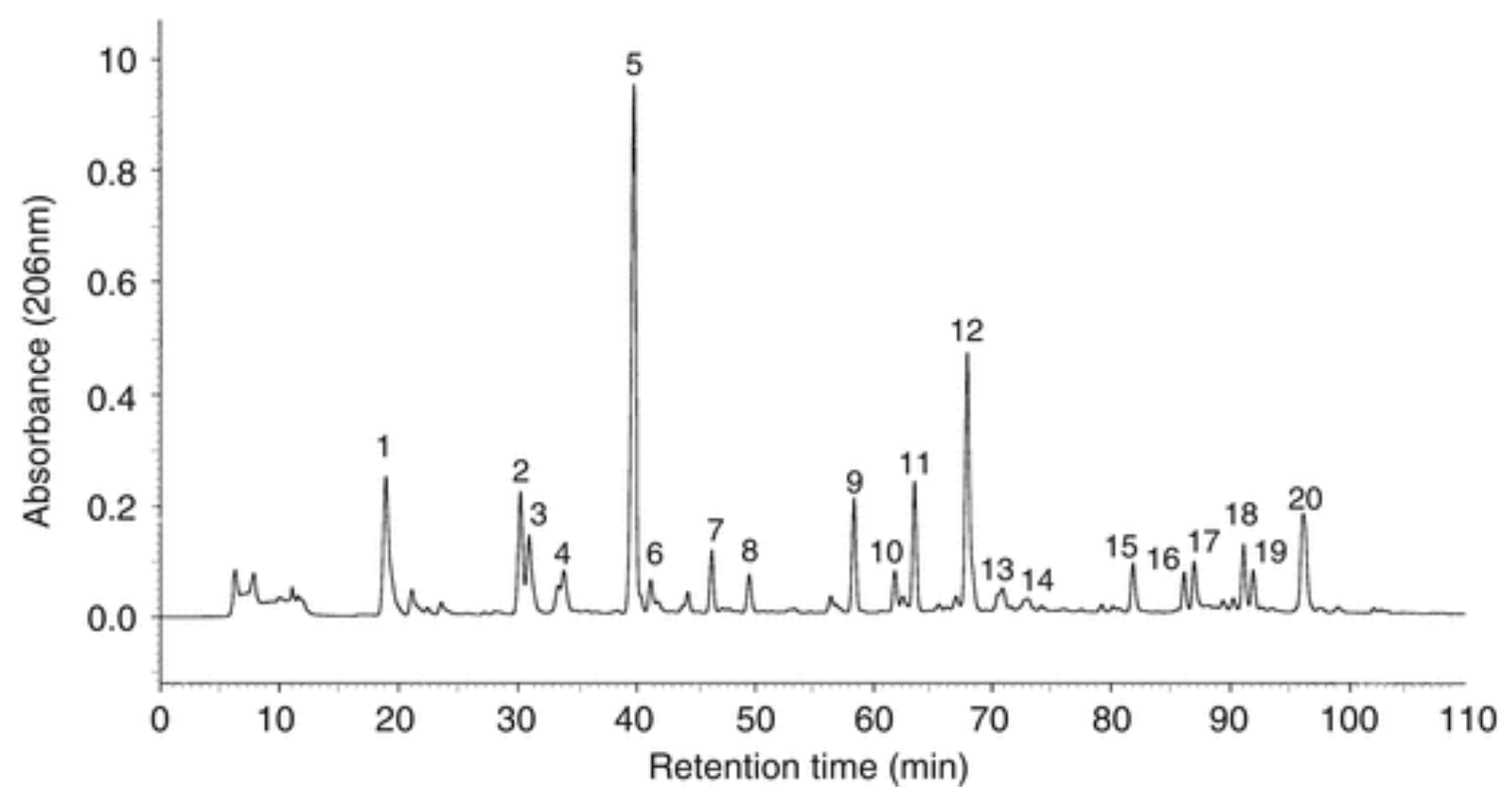

Fig. 1 Example of a muropeptide profile of PG from the Gram-negative bacterium Helicobacter pylori (Adapted from Viala et al. 2004)

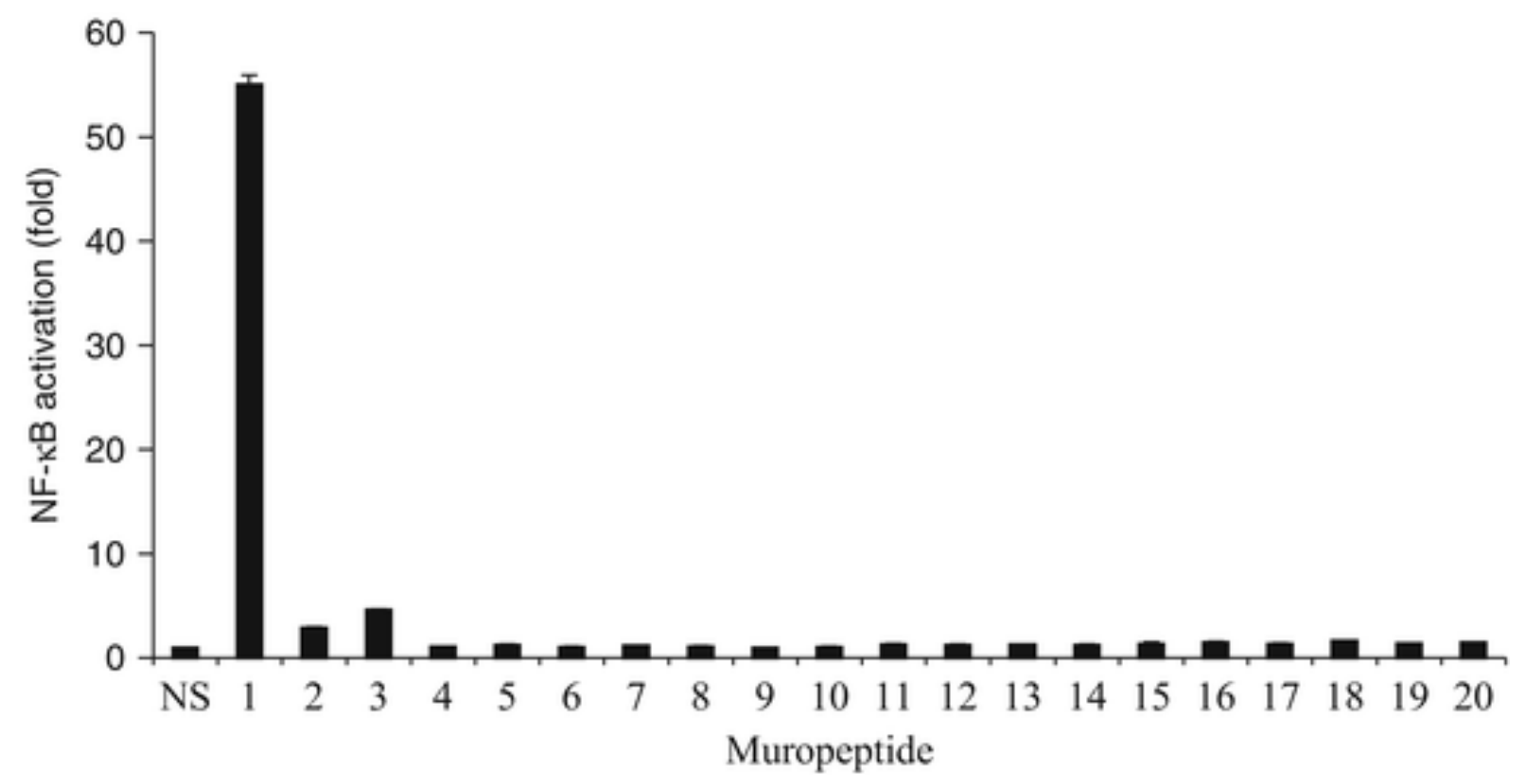

Fig. 2 Example of biological activity towards Nod1 of HPLC purified muropeptides from Helicobacter pylori (Adapted from Viala et al. 2004). Muropeptide numbers correspond to indicated peaks in Fig. 1 